\title{
A Ação Federal sôbre o Ensino Secundário e Superior até 1930
}

\author{
Geraldo Bastos Silva
}

\section{II - ENSINO SECUNDÁRIO (*)}

A reforma Benjamin Constant, como vimos, previa a possibilidade de os exames de maduneza realizados nos estabelecimentos estaduais darem os mesmos direitos de matrícula nos cursos superiores que o exame de madureza prestado no Colégio Pedro II. Essa equiparação, portanto, tinha um significado bem delimitado enquanto peça do projetado mecanismo aperfeiçoador do ensino secundário que analisamos.

Fora dêsse mecanismo, cujas peças fundamentais eram, justamente, o exame de madureza e a equiparação, nenhuma ação federal se pretendia sôbre os estabelecimentos estaduais. E, se pela atribuição ao exame de madureza, prestado nos estabelecimentos estaduais, do mesmo valor do exame de madureza feito no Pedro II, ficava intocado o princípio federal da autonomia dos Estadus, pela prestação, nos estabelecimentos oficiais - o federal ou os estaduais equiparados, - do exame de madureza dos alunos dos estabelecimentos particulares, ficava respeitada a liberdade do ensino privado, através da desnecessidade de equiparação dêstes últimos.

Mas, antes que se realizasse o exame de madureza, para que não apenas os alunos do Pedro II tivessem a necessária habilitação para ingresso nos institutos de ensino superior, impunham-se os exames de preparatórios, equivalentes, para os alunos provenientes de outros educandários, dos exames finais do estabelecimento federal.

A realização das provas dos candidatos a preparatórios juntamente com os exames finais dos alunos do Pedro II, atendia apenas ao caso do Distrito Federal. Assim, prevêem-se exames de preparatórios fora do Pedro II, primeiro, pela reforma dos cursos jurídicos de janeiro de 1891, nos cursos anexos das Faculdades de Direito e "nos ginásios particulares a êste equiparados por decreto do Govêrno", \&, em seguida, nos estabelecimentos estaduais, independentemente de equiparação, pelo decreto $\mathrm{n}^{\circ} 1.389$, de 21 de fevereiro de 1891, que "torna extensivo aos estabelecimentos oficiais dos Estados" o disposto na citada reforma dos cursos jurídicos, sôbre exames de preparatórios nos colégios particulares.

(*) Conclusão do Vol. 69, n. ${ }^{\circ}$, dez, de 1955, da "Revista do Serviço Público". 
Poderíamos, dessa forma, falar em duas espécies de equiparação, com referência ao período em que vigorou a reforma Benjamin Constant: a dos estabelecimentos estaduais, concebida em função do exame de madureza, e a dos estabelecimentos particulares, relativa apenas aos exames de preparató. rios e, portanto, vigorante sòmente para o período anterior à exigência de aprovação em exame de madureza para ingresso nos cursos superiories.

O propósito de restringir ao reconhecimento do exame de madureza, prestado nos institutos estaduais a ação central sôbre o ensino secundário de iniciativa não federal, adquire maior vigor com a promulgação da Constituiçäo de 24 de fevereiro. E por causa disso apesar do Decreto n. ${ }^{\circ} 14389$, aliás anterior de três dias apenas à data da Constituição - para que os exames de preparatórios prestados nos estabelecimentos estaduais tivesssem validade para ingresso nos cursos superiores, antes do início da exigência de exame de madureza, foram necessários em cada oportunidade atos especiais que os permitissem.

E vimos que, em relação aos exames de preparatórios permitidos pelo decreto $\mathrm{n}^{\circ} 1.389$, a maioria dos Estados se mostrou desinteressada na organização das bancas na forma prevista, o que ocorreu, segundo o depoimento do então Inspetor Geral de Instrução, justamente por motivo da promulgação da Constituição, em face da qual os Estados teriam autcnomia no que dissesse respeito a ensino secundário.

Pelo menos em parte, decorreu do mesmo motivo, sem dúvida, o fato de que, sòmente em 1892, pela primeira viz, dois Estados requerem e obtêm a equiparação dos institutos de ensino secundário por êles mantidos: o Pará e Minas Gerais. Os decretos que concediam a prerrogativa invocavam em ambos os casos a reforma do ensino secundário, o citado dispositivo da reforma dos cursos jurídicos que previra a equiparação de estabelecimentos particulares para o fim de realização de exames de preparatórios, e o decr,to acima referido, que autorizou a realização dos mesmos exames nos institutos oficiais dos Estados.

Mas o motivo principal do reduzido movimento de equiparações até 1897 residia certamente na dificuldade de os Estados adaptarem a organização de seus estabelecimentos ao padrão instituído pela reforma Benjamin Constant, se não mesmo na resistência a essa adaptação, por motivo de discurdância da orientação prescrita pela reforma ou por mera incapacidade de aderir a seus objetivos em razão da persistência do conceito propedêutico do ensino secundário.

E' mesmo lícito duvidar qua já em 1892 os Estados do Pará e de Minas estivessem capacitados e realmente dispostos a implantar em seus institutos de ensino secundário o plano de estudos da reforma Benjamin Constant, o "ensino secundário integral" da inspiração positivista do seu autor. A acomodação a êsse plano seria, assim, incompleta, imperfeita, não resultando verdădeiramente de adesão aos princípios da reforma.

$\mathrm{O}$ interêsse principal, senão exclusivo, que motivava o empenho de equiparação seria assim a obtenção do privilégio de realização de exames que dessem direito de matrícula nos cursos superiores, o que correspondia melhor ao conceito predominante que se admitia para o ensino secundário. 
E' dentro do quadro constituído pelo referido conceito que, mais plausìvelmente, podemos admitir persistisse em manifestar-se o desejo ou convicção de autonomia, da parte dos Estados.

Desta afirmativa podemos considerar uma corroboração o projeto do senador Américo Lôbo, de 1892, e que antecipa assim de dez anos, para o ensino secundário, o projeto Félix Gaspar a que antes aludimos. Segundo êsse projeto as aprovações do exame de madureza ou os títulos de bacharel dados pelas instituições de ensino secundário que se organizassem nos Estados, e que fôssem criadas ou reconhecidas pelos Governos estaduais, habilitariam à matrícula nas escolas de ensino superior.

E "no caso de não se tornar efetiva a exigência do exame de madureza", acrescentava o projeto, o Govêrno do Estado seria competente para mandar proceder aos exames de preparatórios indispensáveis, nas instituições que êle criasse ou reconhecesse, assim para fiscalizá-los, produzindo as aprovações obtidas todos efeitos, "dentro e fora dos Estados".

O projeto, se transformado em lei, teria, como se vê, realizado a competência estadual em matéria de ensino secundário, como estabelecido estava na Constituição. E o seu fundo pedagógico, por sua vez, era claramente constituído pela concepção preparatória do ensino secundário, tornada ainda mais flagrante no aditivo da Comissão de Instrução do Senado, segundo o qual os exames, para gozarem das regalias concedidas, deveriam ser nealizados peranto professôres escolhidos pelas congregações dos institutos de ensino supe. rior (34).

Em face do dissinterêsse da maioria dos Estados em obter a equiparação de suas instituições de ensino secundário, dirigiu o Ministro, em setembro de 1893, um Aviso-circular aos Governadores que começava assim: "Suscitando-se dúvidas acêrca das condições mediante as quais podem os institutos de instrução nos Estados ser equiparados ao Ginásio Nacional, bem como acêrca da validade dos exames de preparatórios ali prestados, o Govêrno Federal tem por conveniente expor em sintese as disposiçôes regulamentares em vigor sôbre o assunto que sobremodo interessa ao desenvolvimento da instrução". As disposições citadas são as da reforma do ensino secundário e da reforma dos cursos jurídicos de 1891 .

"A verificação da exata e fiel adoção dos programas oficiais, continuavãa - Aviso, bem como da competência do pessoal docente incumbido de executá-los, verificação feita por comissários do Govêrno Federal, tem sido a base estabelecida para a expedição de decretos especiais conferindo a estabelecimentos estaduais, que preencham aquêles requisitos, as vantagens e regalias do instituto federal. Convém pois, que os Estados, logo que tenham organizado, nesta conformidade, os seus estabelecimentos de instruçäo secundária, o comuniquem ao Govêrno Federal, a fim de que possa êste mandar proceder as diligências necessárias para reconhecê-los e, equipará-los ao instituto fæderal".

"Entretanto, prosseguia o Aviso, sendo possível que nem todos os Estados disponham de elementos para instituir curso de instruçäo secundária moldados

(34) Primirivo MOACIR, obr. cit., vol. 2., p: 210 . 
pela organização do Ginásio Nacional, o decreto $\mathrm{n}^{\circ} 1.389$, de 21 de fevereiro de 1891, completando o plano de organização que se contém naquelas disposições, reconhece, para matrícula nos cursos superiores, os exames de preparatórios feitos nos cursos oficiais de ensino secundário dos Estados, uma vez que sejam prestados de acôrdo com os programas do Ginásio Nacional".

Finalmente, lembrava o Aviso o exame de madureza: "Cumpre lembrar, porém, que ex-vi do decreto de novembro de 1890 , sòmente $u$ certificado de estudos secundários ou título de Bacharel, obtidos mediante exame de madureza, dará direito, a contar de 1896 , à matrícula nos institutos de ensino superior, s, pois, cessará dessa data em diante a validade de quaisquer exames de preparatórios". (35)

O Aviso-circular surtiu algum efeito, ainda que um pouco demorado. Em setembro de 1894 é reconhecido o Liceu Cearense. Em 1896 são igualmente equiparados o Ginásio do Estado de São Paulo, o Liceu Paraibano e o Ginásio da Bahia. E em 1897 o Liceu Alagoano e o Liceu Piauiense.

Os atos de 1896 não fazem referência às disposições legais que the servem de fundamento. Mas é curioso assinalar que os de 1894 e de 1897 citam apenas o decreto de 1891 relativo à autorização de exames de preparatórios nos estabelecimentos estaduais, sendo de assinalar que tais exames, de acôrdo com a reforma BENJAMIN Constant do ensino secundário, não deveriam mais realizarem-se depois de 1896, ou, no máximo, 1897.

Isso talvez deva ser interpretado como aceitação, pelo Govêrno Federal, do fato de que o móvel principal, ou mesmo exclusivo, da equiparação era o reconhecimentu da validade dos exames de preparatórios realizados nos estabelecimentos estaduais. Tal aceitação coadunava-se com o crescente deticismo em relação ao exarre de madureza e às demais idéias da reforma BENJAMIN Constant.

Mesmo programada a extinção dos exames de priparatórios, limitaria agora a ação federal sôbre o ensino secundário seus objetivos, restringindo-os a fim de ajustá-los à concepção propedêutica dêsse ensino, face à qual não mais tinha razão de ser a exigência da "exata e fiel" adoção do currículo formativo ideado por BenJAMIN CONSTANT.

$* * *$

O decreto de reforma dos cursos jurídicos, devido a Benjamin Constant, previu que os exames de preparatórios seriam realizados também nos ginásios particulares "equiparados por decreto do Govêrno", como vimos. Esse decreto, onde pela primeira vez se usa o têrmo equiparação, representa a primeira brecha aberta no princípio da liberdade do ensino secundário particular, adotado pela reforma Benjamin Constant, e teria sido também o primeiro passo no sentido da completa uniformização do ensino secundário de todo o país se a equiparação prevista não tivesı̊ permanecido irrealizada.

(35) PrImITIvo MOACIR, obr, cit., vol. $24^{\circ}$, pp. $121 / 2$. 
Havia, de fato, manifesta má vontade da administração federal com referência à concessão de qualquer privilégio aos estabelecimentos particula, res, resultando disso que nenhum déstes obtivesse a equiparação de que cogitara êsse decreto.

E' por isso, também, que projeto de lei do deputado SEVERINo VIEIRA, aprovado pelo Congresso no mesmo ano do citado đecreto, é vetado pelo Executivo apresentadas as seguintes razões: "Dar aos estabelecimentos particulares de ensino a faculdade de habilitarem alunos para estudos superiores, seria comprometer gravemente a causa da instrução pública em nosso país, onde os institutos particulares de ensino secundário são, em sua generalidade, faltos de pessoal docente decididamente habilitado, dispõem apenas de fraquíssimos recursos materiais e carecem absolutamente de uma verdadeira orientação pedagógica. Efetuados os exames no seio dêsses institutos, cujos vitais inte. rèsses estão estreitamente ligados ao número de aprovaçōes dos alunos, que constituem para êles o maior incentivo à confiança e frequêencia pública, não fòra lícito considerar o seu resultado como genuína expressão de um julgamento cabal e sincero". (36)

A atitude que tais palavras traduzem persistirá, ainda que sujeita a certas oscilações, pelo menos até 1899 , quando se tornará definitivamente extensiva aos estabelecimentos particulares a equiparação ao Colégio Pedro II.

As oscilações aludidas têm sua ilustração no caso do Instituto Köpke. Este renomado colégio requereu, em 1893 , a sua equiparação aos estabelecimentos oficiais, para o fim de seus diplomas gozarem das mesmas regalias dos conferidos pelos últimos. Sem dúvida para contornar a atitude pouco acessível da administração federal, dirigiu-se ao Senado. Alegava, em justificação de sua pretensão, entre outras coisas, o fato de seu currículo incluir tôdas as matérias do curso oficial.

A Comissão de Instrução do Senađo deu parecer favorável ao pedido do Instituto Köpke, condicionando, no entanto, a equiparação à fiscalização das congregações dos institutos de ensino superior. Na discussão do projeto, informa PRIMITIVo MOACIR. foi pedido que a providência fôsse extensiva ao Colégio Abílio e a todos os institutos que se organizassem segundo o programa e os métodos do Instituto Köpke. Projeto e emendas são rejeitados antes que o Executivo o vetasse, como vetou o projeto Severino Vieira. (37)

E' o Executivo, no entanto; que, em 1895 - justamente o ano em que não é equiparado nenhum estabelecimento estadual - concede equiparação ao Instituto Köpke, justificando-a por meio de uma interpretação combinada dos dispositivos que estabeleciam a validade do exame de madureza nos colégios estaduais e dos exames de preparatórios nos particulares, e formulando, além disso, o parecer de que a obediência ao plano de ensino do Ginásio Na-

(36) PrImitrvo MOACIR, obr. cit., vcl. 2, ${ }^{\circ}$, pp. 208/9 - "Acresce, diziam ainda as razões do veto, que o processo estabelecido no decreto legislativo contraria de frente o sistema adotado na última reforma do ensino, em virtude do qual as habilitaçôes dos examinandos serào avaliadas, com outra exatidăo, mediante provas sucessivas de suficiência, finais e de madureza".

(37) PrImitrvo MOACIR, obr. cit., vol. 2., pp. $211 / 2$. 
cional, a què se referia o decreto da reforma BENJAMIN CoNSTANT, não poderia "ser entendida no sentido literal e restrito, qual seja o de reputar-se indispensável que os ditos estabelecimentos se adaptem exclusivamente aos programas e processos de ensino do Ginásio", pois isto "seria não sòmente contrário aos intuitos do legislador, ccmo também oposto à índole do regime republicano". (38)

Havia assim, nessa concessão, duas surpreendentes retificações da atitude antetior da administração: a da negativa de concessão da prerrogativa de equiparação a estabslecimentos particulares e a da exigência "da exata e fiel adoção dos programas oficiais", formulada mesmo em relação aos estabelecimentos estaduais, como vimos, pelo Aviso-circular de setembro de 1893 .

Tanto a primeira como a segunda dessas retificações seriam possivelmente outras indicações das crescentes restrições que se vinham fazendo ao espírito e à estrutura da neforma Benjamin Constant.

De um lado significa que não mais se atribuía, com exclusividade, ao currículo de inspiração positivista imaginado por Benjamin Constant aquêle sentido formativo que o reformador pensara introduzir no ensino secundário brasileiro. E, de outra parte, equivalia a um precedente ameaçador da ampla liberdade do ensino de iniciativa privada.

Se aceitarmos como fato a excelência do trabalho educativo realizada no Instituto Köpke (38-A), nem uma nem outra coisa contrariava, a não ser formalmente, o intento de aperfeiçoamento do ensino secundário que era o de Benjamin Constant. Mas, se dentro da peršistente concepção meramente preparatória do ensino secundário o precedente produzisse seus efeitos e, em consequiência, depois do Instituto Köpke, outros colégios de padräo inferior recebessem, como decorrência de idêntica equiparação ou ao menos com base na reforma dos cursos jurídicos, a faculdade de examinarem candidatos a preparatórios, estaria ameaçado todo o resfôrço de aperfeiçoamento do ensino secundário.

Tal não ocorre porque outros colégios particulares não recebem, antes de 1900. as regalias da equiparação, e porque, persistindo a atitude de desconfiança em relação a êsses colégios, as sucessivas prorrogações dos exames de preparatórios restringiam a realização dêstes aos estabelecimentos oficiais.

Mas a tendência para ser dada aos colégios particulares status equivalente ao dos oficiais faz-se sentir cada vez mais aoentuada. E, programada a extinção dos exames de preparatórios, vigorante a reforma BENJAMIN CoNSTANT, teriam, no futuro, os alunos dos colégics particulares não equiparados de prestar exame de madureza nos institutos oficiais. Tal perspectiva não seria do agrado daqueles colégios, e, aduzindo-s̊ a isso a circunstância de crescente descrença em tôrno daquela reforma, compreende-se assim que a equi-

(38) PRIMITIVo MOACIR, obr. cit., vol. $2 .^{\circ}$ p. 78.

(38-A) - JoÃo KöPKE mereceu de Rui Barbosa e de Rangel Pestana palavras elogiosas sôbre seu trabalho como educador. O primeiro viu nele "a intuição, a ciência e a vocação de um Fröbel" (RuI BARBosA - Queda do Império, Rio: Ministério da Educação e Cultura, 1948 - pp. 119/27). 
paração pudesse vir a assumir um alcance maior em relação ao ensino privado, igualando êste ao ensino público para todos os efeitos.

E' o regulamento do Ginásio Nacional, de 1899, baixado de acôrdo com a autorização dada pela Lei . $^{\circ} 560$, de 31 de dezembro de 1898 , a qual mandava rever o regulamento dêste ano, para o fim de permitir a realização de exames de madureza nos colégios localizados nos Estados, que estabelece a equiparação, em pé de igualdade, tanto dos colégios estaduais como dos criados pela iniciativa privada.

Cumpre observar que já oo regulamento de 1898 , baixado por AMARo $\mathrm{C}_{\mathrm{A}-}$ vALCANTE na base de autorização da lei orçamentária do ano anterior, previra as condições para que "os certificados de conclusão de estudos e os graus conferidos pelos estabelecimentos de instrução secundária fundados pelos Estados, associações ou particulares venham ou continuem a ter os mesmos efeitos legais que os dos estabelecimentos federais", portanto para serem os primeiros equiparados aos últimos.

Era a ıquiparação estendida aos colégios estaduais assim como aos particulares. Mas como o mesmo regulamento estabelecia que o exame de madureza teria lugar nas localidades onde existissem cursos superiores, visto como o juri do exame seria constituído de professôres dêstes cursos, não era ainda a equiparação completa.

Era uma equiparação puramente nominal, pois os alunos dos estabelecimentos equiparados ficavam na dependência de um exame, prestado ante professôres do curso superior, para neste terem ingresso. E note-se que o exame de madureza ficava assim com o caráter de exame vestibular, de certo modo, substituindo-se aos exames de preparatórios de cuja realização não participavam também os colégios particulares onde os candidatos tivessem estudado.

A equiparação completa, portanto, só ocorre com o regulamento de 1899 , - qual, abolindo o juri de professôres do ensino superior, para o exame de madureza, permitiu que êste exame tivesse lugar "em tôdas as cidades em que existinem cursos de ensino secundário federais e estaduais, e particulares equiparados aos primeiros". (39) Os alunos dos colégios particulares ficavam assim com a possibilidade de, na mesma localidade, fazerem o curso secundário e adquirirem, por meio de exames oficiais, o direito de ingresso nos cursos superiores.

Mas, sobretudo, alcançando os colégios particulares, plenamente, a situação de instituições oficializadas, abria-se para êles a perspectiva de serem beneficiados com as sucessivas prorrogaçōes do prazo de validade dos exames de preparatórios que o desgaste da idéia de exame de madureza permitia prever.

Desde o regulamento do Ginásio Nacional de 1898, prescrevia-se para a equiparação a observância das mesmas condições exigidas, para a equiparação dos cursos jurídicos, pela lei $n^{\circ} 314$, de 30 de outubro de 1895 . O assunto

(39) Primitrvo MoAcrR, obr. cit., vol. $3 .^{\circ}$, p. 91. 
é regulado por instruções de 1899 (decretos ns. 3.285 , de 20 de maio, $\theta$ 3.491, de 11 de novembro), consolidadas depois pelo Código Epitácio Pessoa.

Note-se que, logo em fevereiro de 1900, o antes citado Instituto Köpke tem cassada a equiparação anteriormente concedida, entre outros motivos, enunciados no decreto que promoveu a cassação, porque, face as instruçōes de 1899 , não podiam subsistir os têrmos do decreto que concedera o favor, "no concernente à adoção do plano e programas de ensino".

E' que a equiparação indiscriminada introduzira algo novo no pancrama do ensino secundário brasileiro: o intento de uniformização de todo o ensino dêsse tipo, quer o dependente dos poderes públicos, quer o de criação da iniciativa privada, de acôrdo com o modêlo prescrito pelo Govêrno Federal.

Não apenas por ter consolidado a equiparação, tanto dos colégios particulares como dos estaduais, e por ter introduzido nessa o sentido de uniformização de todo o ensino secundário nacional, a reforma Epitácio Pessoa marca uma nova etapa na evolução dêsse ensino, representando assim o término da fase começada com a reforma Benjamin Constant.

Também em relação ao currículo e a outros aspectos da organização didática do ensino secundário essa nova reforma teve o sentido de consumar o encerramento do ciclo iniciado, logo após 1889 , pela primeira reforma republicana do ensino secundário.

O assunto da equiparação está regulado no próprio Código Epitácio Pessua (Código dos Institutos Oficiais de Ensino Superior e Secundário, dependentes do Ministério da Justiça e Negócios Interiores - Decreto n. ${ }^{\circ} 3.890$, de 1 de janeiro de 1901).

Os requisitos para equiparação ficam sendo, além de condições patrimoniais (dispensadas para os estabelecimentos estaduais) e de freqüência, assecuratórias do funcionamento regular dos estabelecimentos, a observância "dò regime e dos programas de ensino do estabelecimento federal".

E, sendo essas disposiçõ̃es gerais, aplicáveis tanto à equiparação de estabelecimentos de ensino superior quanto de ensino secundário, cumpre registrar, para documentar o sentido de uniformização do ensino secundário que a equiparação envolvia, que outros dispositivos estabeleciam que "em relação aos estabelecimentos de ensino secundário se observará mais o seguinte:

I - São de rigorosa observância nestes estabelecimentos as disposições do regulamento do Ginásio Nacional, relativas número e seriação das disciplinas, a sua distribuição pelos anos do curso e ao número de horas semanais consagradas ao estudo de cada matéria.

II - A organização dos programas de ensino é da competência exclusiva đa congregação do Ginásio Nacional $(\ldots)$.

III - São de estrita observância as regras estabelecidas no regulamento do Ginásio Nacional para a execução dos programas, bem como o dispostó com relação aos exames de admissão, de promoções sucessivas, e de madureza. $(\ldots) "$. 
Requerida a equiparação, o Govêrno nomearia um delegado fiscal para observar o estabelecimento no período de dois anos, durante o qual seria averiguada e relatada, semestralmente, a vida escolar em todos os seus aspectos, inclusive com referência ao corpo docente e aparelhamento didático.

Terminado êsse prazo, poderia ser concedida a equiparação, após o qual o estabelecimento continuaria sujeito à fiscalização do delegado fiscal do Govêrno, cujas atribuições o Código de Ensino fixava e Circular de $\mathbf{3 0}$ de abril de 1901 especificou melhor.

O currículo e a organização didática do ensino secundário, estabelecidos pela reforma Epitácio Pessoa, não fazem parte integrante do Código de Ensino. mas do regulamento do Pedro II (Ginásio Nacional) baixado pelo Decreto n. 3.914 , de 26 de janeiro de 1901, como complementação do Código.

O currículo dêsse novo regulamento apenas em pormenores se distingue do de 1899, feito sendo já ministro EPITácio PESSOA, e ao qual nos referimos anteriormente dizendo que êle, salvo pequenas variações, será o currículo da educação secundária brasileira até a reforma Capanema, e assinalando como sua característica marcante um enciclopedismo ainda acentuado.

Além do currículo, e com referência ainda à organização pedagógica do ensino secundário brasileiro, a significação da reforma Epitácio Pessoa, na história da evolução dêsse ensino, consistiu em ter visado de um modo mais preciso, ainda que iem "nível de aspiração" mais modesto, ao objetivo de superar a concepção preparatória.

Já estava então bem identificada essa concepção com a deficiência básica do ensino secundário, que se exprimia nos exames de preparatórios. Não se esperava mais, no entanto, que ela pudesse ser corrigida, de chofre, pela instituição de um currículo pretensiosamente enciclopédico reforçado pela prova purificadora do exame de madureza.

O que se visa é uma transição paulatina do regime de preparatórios para o de estudos secundários feitos com o caráter de curso regular, à obediência nesses estudos de uma idéia de curriculum, no sentido próprio da palavra. Em outros têrmos, o objetivo imediato é a substituição dos preparatórios pelo regime seriado ou, de promoções sucessivas, como então se chamava.

E' um objetivo modesto, sem presunção de originalidade, pois o insino seriado já estava previsto na reforma BenJAmin Constant. Mas, nesta última, êle é apenas um aspecto ou decorrência do plano de estudos inspirado na crdem lógica de classificação das ciências, de CoMTE, e a restrição da equiparação aos estabelecimentos estaduais resultava em que só nestes, e no Pedro II, se o pretendia impor diretamente: para o ensino secundário particular sòmente se previa, como mecanismo corretor da concepção preparatória, o exame de madureza que seus alunos deveriam prestar em estabelecimento oficial.

Na reforma EPITÁcio PESSOA, ao contrário, é da equiparação, estendida também aos estabelecimentos particulares, que se espera que o regime de estudos seriados se substitua, progressivamente, à simples preparação imediatista aos exames de habilitação para matrícula aos cursos superiores. 
Os exames de madureza são mantidos, cumpre observar, devendo realizarem-se no Distrito Federal perante o Colégio Pedro II, e, nas outras cidades, nos oficiais equiparados. Sòmente quando êstes últimos não existissem, puderiam tais exames ter lugar nos colégios particulares.

A equiparação, estendida tanto aos estabelecimentos estaduais quanto aos particulares, andava a par com a implantação progressiva do regime de estudos seriados nos institutos equiparados: um dispositivo do regulamento do Pedro II, a ser observado também nos colégios equiparados, previa que a admissão aos cursos se poderia fazer, sempre mediante exames, tanto à série inicial como às séries intermediárias.

Dar-se-ia, assim, à proporção que fôsse crescendo o número de estabelecimentos equiparados, 2 desde que fôsse sendo reconhecida a superioridade do regime de estudos seriados, a substituição, por êste, do sistema de preparação imediatista para exames de preparatórios.

Sob a regulamentação baixada por Epitácio Pessoa, começa, desde 1901, a ser concedida equiparação a numerosos estabelecimentos particulares e estaduais, crescendo ano a ano o número de colégios equiparados.

Mas, ainda uma vez, verá a administração federal malograr-se o seu intento de obter uma organização do ensino secundário que superasse a concepção preparatória, a qual tem ainda tamanha fôrça - que determina as sucessivas prorrogações da exigência do exame de madureza em benefício dos exames de preparatórios, como vimos.

E a administração adota, em face dessas prorrogações dos exames preparatórios, a diretriz de limitar sua realização aos estabelecimentos oficiais, não concedendo a prerrogativa de realizá-la aos particulares.

Essa limitação obedecia ao propósito de dar a êsses exames uma seriedade de que era evidente que êles cada vez mais se afastariam, se também nos colégios particulares tivessem lugar.

E' incontestável e compreensível que o ensino secundário particular padecia, salvo porventura exasções, da mesma limitação daquela concepção preparatória, e, assim, voltava-se para os exames oficialmente reconhecidos como para o principal objetivo a ser conquistado.

A confirmação dessa afirmativa temos no uso que, de início, quiseram fazer ortos colégios particulares, do dispositivo do regulamento do Pedro II que permitia exames de admissão a qualquer série do curso, após o ingresso no qual o aluno deveria continuar os estudos seriadamente.

Mais de uma vez foi o Ministro obrigado a dirigir-se a certos colégios ou a seus fiscais, a fim de evitar que alunos fizessem tais exames e, em seguida, se thes concedessem certificados como se fôssem de exames de preparatórios. o que constituiria uma burla da proibição de tais exames nos colégios particulares, e um emprêgo abusivo das prerrogativas da equiparação. (40)

(40) V. Decisões do Govêrno, na parte relativa ao Ministério da Justiça e Negócios Intericres: $1900, \mathrm{n}^{\circ} 54$ (de 26 de outubro), e 1901, n. ${ }^{\circ} 18$ (de 27 de abril). 
A equiparação, portanto, não era procurada por motivo de uma adesão sincera e completa à idéia de ensino seriado. mas com o propósito de obtenção do direito de concessão de certificados e diplomas ıquivalentes aos do estabelecimento federal, para fins de matrícula nos cursos superiores, sem que os alunos dos estabelecimentos particulares precisassem para isso submeter-se a exames nos estabelecimentos oficiais, com intuitos outros ou por se sentir a ausência de significação educacional de tais exames.

E para isso os colégios particulares, assim como os estaduais, abdicavam de quaisquer veleidades de autonomia pedagógica - para a qual, aliás, a inaioria dêles talvez não estivesse capacitada - para determinação de seus planos de ensino e dos demais aspectos de sua organização pedagógica.

E a administração federal aceitava ıssa abdicação, a fim de poder exercer, sôbre o ensino secundário de todo o país um papel disciplinador e aperfeiçoador que lhe era imposto por sua posição em face do ensino superior, e que bem se coadunava com a concepção preparatória, e a fim de não se perder, pelo menos, a possibilidade de o ensino secundário preencher eficientemente sua função propedêutica ao ensino de nível superior.

$\mathrm{E}$ é dessa forma qus a equiparação, estendida a todos os colégios, firma-se como instrumento da tendência à uniformização do ensino secundário. em todo o país.

Mas note-se, essa uniformização não se fazia pela atuação interna de um amplo conceito unificador da educação secundária, mas pela influência externa e acidentalmente tornada absorvente da necessidade de os alunos dos outros estabelecimentos, além do federal, terem os exames nêles realizados reconhecidos para efeito de matrícula nos cursos superiores.

$$
* * *
$$

O contrôle fiederal sôbre o ensino secundário de todo o país, estabelecido pela reforma EPITÁcio PESSOA a efetivado por meio da equiparação e conseqüente fiscalização dos estabelecimentos de ensino secundário, não alcança o objetivo de dar a êsse ensino um sentido educativo próprio.

A equiparação, por meio da qual se visava a impor um tipo uniforme a todos os estabelecimentos de ensino secundário, não se mostrou instrumento eficaz para levar o ensino secundário brasileiro à adoção de uma organização que cornespondesse à direção processo de desenvolvimento dos educandos segundo o critério de objetivos pedagógicos perfeitamente definidos. Operou contra isso a porta aberta dos exames de admissão a qualquer série do curso assim como a facilidade nas concessões de equiparação, ao que se acrescentavam as sucessivas concessões de exames preparatórios. (41)

(41) Sôbre a execução do Código Epitácio Pessoa, diz José Bernardino Paranhos da Silva (Consolidação da legislação federat do ensino superior e do ensino secundário Rio: Tip. Revista dos Tribunais, $1918-$ p. I): "Avisos e oficios os mais incongruentes, em flagrante contradição com a letra e o espírito da lei, geraram na sua vigência tais abusos e incongruências que se fêz necessária nova remodeleção do ensino". - Sôbre o excesso de equiparaçôes, dirá Maximilano, om 1915 (Primitivo Moacir, obr. cit., vol. 
A fiscalização, por sua vez, não conseguia sequer fazer com que os exames realizados nos estabelecimentos equiparados fôssem mais do que formalidades - ao menos isentas do dolo - destinadas a dar aos alunos os certificados que os habilitassem à matrícula nos cursos superiores.

Nos relatórios ministeriais, pesquisados por PRIMITrvo MOACIR, encontramos farto material evidenciador do estado precário do ensino secundário e do reduzido rendimento da ação federal sôbre o mesmo.

Já em 1902 dizia o Ministro SABINo BARRoso: "O ponto fraco do regime das equiparações reside todo na dificuldade de fiscalização. Sem tornar-se ela efetiva, melhor seria abolir o sistema". (42)

Esse Ministro, de fato, procurara, por meio de circular do ano anterior, e em consonância com êsse seu modo de entender, enquadrar a ação dos delegados fiscais dentro de uma estrutura de atribuições mais minuciosa do que o tinha feito o Código Epitácio.

Mas êle mesmo se mostrava, em seguida, descrente da eficácia da fiscalização, quando dizia, no mesmo relatório: "Quem conhece o mecanismo dêsses colégios e a latitude que se pode dar ao disposto no art. 30 do Regulamento do Ginásio Nacional (exame de admissão a qualquer série do curso), sabe quanto é relativamente fácil reduzir o curso seriado a um ou dois anos e transformar o exame de admissão em verdadeira sucursal dos exames parcelados". (43)

Em 1903, o Ministro J. J. Seabra, por sua vez dizia: "Êste desfalecimento (da instrução) foi-se acentuado pcuco a pouco e nestes últimos anos agravou-se sobremancira com o regime de equiparação de colégios". (44) $\mathbf{E}$ aduzia mais adiante: "Para a decadência do ensino secundário muito têm concorrido os colégios equiparados com a faculdade de darem certidão de exames válidos para matrícula nos cursos superiores, e o processo condenado de exame de preparatórios..." (45)

No ano seguinte o mesmo Ministro, ao reiterar suas acusações aos colégios equiparados, não esquecia de criticar também o estabelecimento federal, cujo

\begin{abstract}
4..$^{\circ}$ p. 154): "Por largo tempo figurou em lei a faculdade da equiparação dos institutos particulares de ensino secundário, sem que dela usasse o govêrno, receoso dos seus efeitos. Passado ésse período, que muitos anos não durou, enveredou o govêrno pelo caminho das equiparaçōes em massa $e$ os seus atos mais pareciam alucinaçōes de um transviado ou brinco de criança que resoluçôes ponderadas de quem tem a responsabilidade da administração. Não houve colégio particular nas capitais, ou em longínquo centro dos Estados que, amparado pelo delegado da zona, ou representante do distrito eleitoral, não fôsse logo, sem qualquer dificuldade e sem mínimo exame, equiparado ao Ginásio Nacional". Paranhos da Silva dá em seu livro a relação dos estabelecimentos particulares e estaduais que, ao ser decretada a lei Rivadavia, gozavam de equiparação: são, ao todo, 76 colégios, dos quais 59 obtiveram a regalia depois de 1900, sendo 10 nêste único ano e 20 em 1908 (obr. cit., pp. 553/5).
\end{abstract}

(42) PrIMITIVo MOACIR, obr. cit., vol. $30^{\circ}$, p. 116.

(43) Primitrvo MoAcir, obr. cit., vol. $39^{\circ}$, p. 118.

(44) Primitrvo MOACIR, obr. cit., vol. $3 .^{\circ}$, p. 93.

(45) Primitivo MoAcIR, obr. cit., vol. 3. , p. 96. 
ensino recunhecia "falho, improfícuo e defeituoso". "Se o ensino no Ginásio (Nacioral) deixa tanto a desejar, o que dizer do ministrado nos colégios equiparados a dos que visam o preparo de alunos para os já famosos exames parcelados?" E citava as palavras de DUNSHEE DE ABRANCHES, Diretor Geral de Ensino. que resumia a situação do ensino secundáro nas seguintes palavras: "o mau ensino no Ginásio, o péssimo ensino nos institutos equiparados, o nulo ensino revielado pelos mercadores avulsos de exames parcelados de preparatórios". (46)

E, ainda neste relatório, o Ministro chega a tomar a defesa da equiparação: "Entre as causas apontadas como justificadoras da decadência do ensino secundário, o regime de equiparação de colégios parece ter sido a que mais impressionou a Comissão de Instrução da Câmara dos Deputados... Sinto dissentir do modo de ver da comissão. (...) Antes das primeiras equiparações já o ensino secundário se achava anarquizado; já o que era dado no Ginásio Nacional se revelava fraco e improfícuo. Desta época para cá, o ensino não melhorou naquele instituto, tendo, ao contrário, piorado, como dizia o seu ú'timo diretor. Ora, se funciona mal o estabelecimento modêlo, como exigir excelências dos que the são equiparados? Se o rebaixamento do ensino secundário dependesse apenas do mau funcionamento dos colégios equiparados, não haveria mister de um ato do poder legislativo suprimindo-os ou dificultando-lhes a organização; ao govêrno, incumbido de fazê-los fiscalizar, sobejariam recursos dentro da lei vigente para chamá-los ao cumprimento do dever..." (47)

Era o neconhecimento de que o problema não poderia ser resolvido por meio de fiscalização, apenas, mas que decorria de um mal mais profundo: "No Brasil considera-se ainda a instrucão secundária como simples passagem obrigada para os que se destinam às profissőes liberais; e como ao transpor - limiar dos cursos superiores se exige do candidato a exibição de um certo número de certificados de exames, transformou-se o nosso ensino secundário em uma perfeita indústria dêstes certificados". (48)

Como sanar o mal? "O meio mais acertado... é deixar a instrução sュcundária entreque à iniciativa particular, desoficializar o Ginásio"... Essa spinião, que não era isolada, pois a idéia de liberd॰de do ensino continuava muito viva, seria idêntica à de Rivadávia, e a solução proposta prenuncia a que êste faria adotar em 1911: "Estou firmemente convencido de que o ensino secundário e superior entre nós, dizia o Ministro, carece antes de tudo libertar-se da ação perturbadora dos poderes públicos; não pode continuar a mercê das modificaçōes a alteraçōes nêle anualmente feitas de afogadilho e năo raro consultando interêsses limitados". (49)

Já o Ministro Tavares LIRA, em 1907, ainda que concordando com o diagnństico do mal básico do ensino secundário brasileiro, mostra-se pouco

(46) PrImitrvo MOACIR, obr. cit., vol. $39^{\circ}$, p. 96.

(47) Primitrvo MOACIR, obr. cit., vol. $30^{\circ}$, p. 98.

(48) Primitrvo MoAcir, obr. cit., vol. $3 .^{\circ}$, p. 98.

(49) PrImitrvo MOACIR, obr. cit., vol. 3. , p. 103. 
solidário com a pregação preparatória da próxima liberdade do ensino, que será adotada em 1911, com a lei RIVADÁviA, apesar de indicar a medida que seria o único resultado benéfico dessa lei, a vigorar durante quatro anos: a instituição dos exames vestibulares.

Desprender o ensino secundário do superior, "exigindo para êstes novos processos de habilitação, com a criação de exames verificadores de capacidade" e atenuar "a ação maléfica dos estabelecimentos equiparados, pela proibição de novas equiparações e fiscalização séria dos que já a obtiveram" parecia a TAVARES LIRA "um dever iniludível, tão iniludível quanto a reform.a do Ginásio Nacional, para que não se percam as suas tradições e seja um verdedeiro tipo modelar..." (50)

Mas as idéias do Ministro TAVAREs LiRA, que êle corporifica numa série de medidas, em 1908, as quais chegam a ser enviadas ao Congresso como projeto de lei (51) não têm maior repercussão. Estávamos maduros para a liberdade de ensino...

Do Ministro Rrvadévia são as seguintes palavras, no ano de 1910: "De fato, o ensino desceu até onde podia descer: não se fazia mais questão de aprender ou de ensinar, porque só duas preocupações existiam, a dos pais querendo que os filhos completassem o curso secundário no menor espaço de tempo possível e a dos ginásios na ambição mercantil, estabelecendo-se as duas fórmulas: bacharel quanto antes; dinheiro quanto mais" (52)... e o Ministro transcrevia um trecho do relatório geral do Congresso de Instrução Secundária reunido, no mesmo ano, em São Paulo: "Vê-se do precedente resumo das sessões que em todos os trabalhos do Congresso houve uma nota dominante, a da denúncia do torpe mercantilismo introduzido no ensino pelo regime da equiparação. Havia muito que as queixas eram gerais entre os educadores sérios; mas o primeiro brado de alerta partiu dos colégios particulares de São Paulo, que lutavam com desvantagem contra a concorrênciá dos istabelecimentos venais". (53)

Mais adiante o Ministro pinta com mais minúcia certos aspectos da situação đo ensino: "Nem mesmo a permanência nos Colégios de ensino secundário durante os anos regulamentares para o estudo seriado das matérias que constituem o curso era uma realidade, e não o era por que o aluno, podendo fazer o exame de admissão a qualquer ano, não estando obrigado a começar pelo primeiro a fim de seguir a seriação natural do ensino, apresentava-se ao instituto do qual pretendia um título para penetrar nas escolas superiores, requerendo admissão a um ano qualquer, muitas vêzes ao último, e, após um exame de formalidades, em que marchavam de harmonia os desejos dos examinandos e os interêsses dos examinadores, tinha ingresso no colégio e daí a um ano ou dois estava habilitado a empreender a conquista da carta de bacharel ou doutor". (54)

(50) Primitrvo MOACIR, obr. cit., vol. 3. ${ }^{\circ}$, pp. 104/5.

(51) PrIMITIVo MOACrR, obr. cit., vol. $30^{\circ}$, pp. $107 / 8$.

(52) PrIMITIVo MOACIR, obr. cit., vol. $3 .^{\circ}$, p. 71.

(53) Primtrivo MoAcrR, obr. cit., vol. $39^{\circ}$, p. 71.

(54) PrImITIVo MOACIR, obr. cit., vol. $3 .^{\circ}$, p. 72 . 
O remédio para tudo isso seria a liberdade de ensino, e a reforma de 1911 a condensa no Lei Orgânica do Ensino Superior e Fundamental da República, elaborada pelo Ministro RIVADÁvia.

Em relação ao ensino secundário, o objetivo da Lei Orgânica do Ensino Supericr e Fundamental da República (Decreto n. ${ }^{\circ} 8.659$, de 5 de abril de 1911) era fazer com que êsse nível de educação adquirisse um conteúdo próprio, deixando de ser mero estágio preparatório do ensino superior. Para o estabelecimento oficial - que volta então a denominação de Pedro II tal objetivo é formulado expressamente: os programas de seus cursos deveriam "revestir-se de caráter prático e libertar-se da condição subalterna de meio preparatório para as academias".

Para o ensino secundário em geral a consecução do mesmo objetivo era esperada da extinção da equiparação e dos privilégios dos diplomas e certificados, concedidos sob fiscalização oficial, e da instituição, em lugar de tudo isso, do exame de admissão às escolas superiores.

O postulado sôbre que se fundavam tôdas essas isperanças era, portanto, o de que, livre o ensino secundário das peias dos regulamentos impostos, enveredasse êle pelo caminho de um desenvolvimento funcional intrìnsecamente valioso. O exame de admissão dos cursos superiores, para cuja inscrição nenhuma exigência de comprovação de estudos secundários anteriores era feita, habilitaria "a um juízo de conjunto" (55) sôbre o desenvolvimento intelectual e a capacidade do aluno para empreender eficazmente o estudo das matérias que constituiriam o ensino das faculdades. Vê-se, assim, que tal exame deveria corresponder ao mesmo fim dos exames de madureza da reforma BenJAMin Constant, porém com um sentido muito mais liberal, pois, em vez de versar sôbre as matérias de um currículo prescrito, visavam habilitar a um "juizo de conjunto" sôbre o desenvolvimento e a aptidão.

Tal postulado exigiria, sem dúvida, condições outras da mentalidade coletiva e de seu reflexo pedagógico, que, infelizmente não existiam, como fatos anteriores tinham demonstrado, nem podiam ser criadas, de improviso, pelo milagre da liberdade.

Haveria mais do que êsse postulado e suas implicações, e do que o princípio de liberdade, que seria o único a traduzir legitimamente o sentido da Constituição? Palavras do Deputado ÉRICo CoElHo, defendendo a reforma no Congresso, sugeriria que sim. "Seria embaraçoso ao Govêrno Federal, dizia êle, cassar as cartas de uns tantos institutos, adaptados ao padrão do Ginásio Nacional, que se desacreditaram. Foi mais fácil, mais conveniente e menos estriepitoso arrasar o privilégio dos diplomas dos bacharéis em letras, não sć os conferidos pelo Ginásio Nacional, como também por outros liceus a êle equiparados"...

(55) Primitrvo MOACIR, obr. cit., vol. $4 . \%^{\circ}$, p. 24.

(56) PrImitivo MoAcIR, obr. cit., vol. $4 .^{\circ}$ p. 67 - No mesmo sentido MAXrMILIANo dirá, em 1915: "Serviço relevante prestou a Lei Orgânica do Ensino tornando de nenhuma valia os exames ginasiais. Era, no momento, o meio rápido de acabar, sem lití- 
De qualquer maneira, compreende-se que os resultados da reforma não podiam ser satisfatórios. Pelo menos porque o exame de admissão às faculdades, na forma em que era estabelecido, não podia suportar, de melhor mođo do que os exames parcelados de preparatórios, o pêso da responsabilidade que se the atribuía: constaria êle, nos têrmos da lei, de uma prova escrita, em vernáculo, "que revele a cultura mental que se quer verificar e de uma prova oral sôbre línguas e ciências".

Tal exame pretendia ser o substituto do exame de madureza, mas não conseguia ser mais do que uma reedição ampliada dos preparatórios, e isto nas faculdades oficiais, (pois nas academias elétricas o ingresso então fácil como o ligar-se um simples comutador...). . $O$ que outrora era um abuso (os exames de preparatórios), dirá em 1915 o Ministro Maximiliano, hoje se tornou lei. Acumulavam matérias (para fazerem exame de preparatórios num só ano) os imprevidentes e os precipitados: agora todos são obrigados a acumular" (57)

Os resultados da reforma RIVADÁvia, portanto, foram os mais desastrosos. Sê-lo-iam menos, talvez, se a liberdade do ensino secundário não se tivesse acompanhado da do ensino superior, e se outras fôssem as circunstâncias so ciais e morais que condicionavam a educação nacional. Dadas estas circunstâncias, o fato incontrovertível foi que a desoficialização de um e a do outro grau do ensino mùtuamente se reforçaram para acentuar o estado de decadência da instrução.

"Se antes dessa lei, diria o deputado Augusto Pestana, no mesmo ano de 1915, mau era o ensino, deficiente o processo de exames, estando quase todo êle entregue à indústria particular, que mais se preocupava com a renda do instituto que com o rigor do estudo e o aproveitamento do aluno, após tal lei não mais existiu ensino secundário no país, salvo em raros institutos, raras exceções". (58)

gios, com os privilégios dos equiparados." (Primitivo Moacir, obr. cit., vol. $4 .^{\circ}$, p. 90). - Convém recordar, finalmente, as palavras, já citadas, do próprio Rivadavia: "A situação não comportava paliativos, era necessária uma organização radical e sistemática ou melhor fôra que o ensino procurasse remédio para os seus males na própria anarquia e descrédito que o avassalavam" (Primitivo Moacir, obr. cit., vol. 4..$^{\circ}$ p. 74).

(57) Primitrvo MOACIR, obr. cit., vol. $4 .^{\circ}$ p. 88.

(58) Primitrvo MOACIR, obr. cit., vol. $44^{\circ}$, p. 161 - Sôbre os efeitos da lei Rivadavia no Pedro II, diz Paranhos da Silva (obr. cit., p. V): "A Lei Orgânica, aliás com - elevado intuito de estabelecer a concorrência entre o elemento oficial e o particulat dêste ramo de instrução, foi tão infeliz que acabaria fechando as portas do Colégio Pedro II, por falta de alunos, se não fôsse a clarividência de Raja Gabaglia, dando no momento maioı amplitude ao quadro de alunos gratuitos. Fôra preferível então que se houvesse suprimido o ensino secundário oficial". - Em 1915, diria MAXIMILIANo: "Cumpre restaurar o glorioso Pedro II, que ora agoniza" (PrIMrTIvo MOAClR, obr. cit., vol. 4.․ p. 89 ), e, em outra ocasião, dirá que o Colégio "estava reduzido a asilos de meninos pobres" (Pritnitivo Moacir, obr. cit., vol, $4 .^{\circ}$, p. 167). 
Nesse ano de 1915, é a lei Rivadávia substituída pela lei elaborada por Carlos Maximiliano, o grande constitucionalista, que havia muito se vinha preocupando com as coisas do ensino, no Congresso.

Também em relação ao ensino secundário, a reforma Maximiliano reinicia o processo de ampliação das funções da administração federal de ensino, no sentido do exercício de atividade normativa e fiscalizadora sôbre o ensino secundário de todo 0 país.

Contràriamente ao Código Epitácio, no entanto, essa atividade não se orienta no sentido de uma rigorosa uniformização do ensino secundário. O pensamento de Maximiliano, sem cair nos excessos de Rivadávia, ainda é marcadamente liberal, sendo, ao mesmo tempo, realista e desambicioso, e demonstrando compreensão e tolerância face às deficiências do meio: "A lei é tanto menos imperfeita quanto mais se adapta áo meio para o qual foi promulgada", diz Maximiliano.

Sua preocupação, relativamente ao ensino secundário, não é mais do que melhorar, ou firmar em bases menos precárias, o desempenho da função pro. pedêutica ao ensino superior, função que o ensino de segundo grau vinha tendo como principal ou exclusiva. Coloca-se assim entre parêntesis aquela inoperante obsessão contra os exames de preparatórios, que enccritramos nas reformas Benjamin Constant e Epitácio Pessoa e, também, em certo sentido, na lei Rivadávia.

Quanto a isso, a interpretaçāo de Maximiliano sôbre as anteriores reformas Epitácio e Rivadávia exprime-se nas seguintes palavras da exposição de motivos da sua reforma: "Tínhamos outrora os exames gerais de preparatórios, com o inconveniente de prestarem os audazes protegidos dez exames de uma vez. Em vez de proibir a acumulação, introduziu-se o curso ginasial. Desmoralizou-se êste com a prodigalidade das equiparações. (...) Instituiuse por isso, o exame de admissão (vestibular), em que o jovem é ao mesnio tempo inquirido doze preparatórios". (59)

E, no seu primeiro relatório depois da reforma, exclamará: "Tornemos aos exames parcelados que preparam sòlidamente as brilhantes gerações do Império e as primeiras figuras da República. Adicionemos uma conquista do progresso, o exame vestibular, que à porta das academias ainda joeira as incapacidades e faz cair as incompetências". (60)

Realmente, manter das reformas precedentes o que nestas houvesse progressivo e fôsse conciliável com a experiência anterior, foi a preocupação de Maximiliano: assim, da lei Rivadávia conserva êle o exame de admissão às escolas superiores; do Código Epitácio Pessoa o ensino seriado, nos estabelecimentos oficiais, e a redução do currículo; da reforma Benjamin Constant

(59) PrImitrvo MoAcir, obr. cit., vol. $4 .^{\circ}$, p. 88.

(60) PrIMITIVO MOACIR, obt. cit., vol. $4 .^{\circ}$, p. 168. 
a restrição da equiparação aos istabelecimentos estaduais; e da relativamente longa experiência brasileira de ensino secundário os exames de preparatórios.

O exame vestibular perdia "aquêle absurdo caráter de um falho exame de madureza", suas palavras de Paranhos da Silva, (61) para assumir o seu verdadeiro papel, que seria segundo Maximiliano, o "de contrastear o prs paro fundamental reconhecido pelos ginásios oficiais", rejubilando-se o reformador, no relatório citado, com o "ótimo resultado da primeira experiência": dos alunos que passaram nas provas dos ginásios, "mais da metade sucumbiu no ádito dos cursos superiores" e, como conseqüência, baixara a matrícula de alunos novos, nos institutos federais de ensino superior, de 1.302 em 1915 , para 144 em 1916. (62)

Não era contudo o júbilo perverso diante um espetáculo de destruição, mas o entusiasmo que acompanhava a certeza de se ter encontrado, agora, no rigor do vestibular, o meio certo de melhoramento do ensino: "Este ano o número de reprovados será incomparàvelmente menor, diminuindo mais em 1917, porque os candidatos apresentar-se-ão a exame cada vez melhor preparados. O primeiro passo foi dado no bom caminho". (63)

Ainda que o sentido geral da reforma Maximiliano seja o de aceitar a concepção preparatória do ensino secundário, adota ela, para o Pedro II e para os estabelecimentos a êste equiparados, a seriação dús estudos: os alunos não poderiam prestar exames, de uma só vez, das matérias de mais de um ano do curso.

E o currículo, acentuadamente reduzido, se comparado com o da reforma Benjamin Constant, inclui, em cada série, quatro a seis disciplinas, abrangendo seis anos de curso: a sexta série - a série de revisão, ou de preparação ao exame de madureza, no Código Epitácio Pessoa - é extinta, porque a experiência demonstrara a sua inutilidade. (64)

A restrição da equiparação aos estabelecimentos estaduais, \& a expressa proibição de concessão dessa prerrogativa a estabelecimentos particulares, quer pertencessım a congregações religiosas, quer fôssem fundadas sem propósito de proselitismo, tem sua justificação feita da seguinte maneira: "Se a Constituição estabelece que será leigo o ensino ministrado nos istabelecimentos públicos, se não pode equiparar aos estabelecimentos públicos os particulares, onde o ensino é religioso. Por outro lado, experiência dolorosa evidenciou a quantos escândalos nos leva a faculdade outorgada a donos de colégios para conferirem diplomas de bacharel em letras". (65)

Tais palavras revelam o homem de govêrno duplamente cioso da pureza da atividade reguladora do Estado: no que dizia respeito aos colégios

(61) PARANHOS DA SILVA, obr. cit., p. 63.

(62) PRIMITIVo MOACIR, obr. cit., vol. $49^{\circ}$, p. 169.

(63) Primitrivo MOACIR, obr. cit. vol. $4 .^{\circ}$ p. 170.

(64) "Inútil manter o sexto ano, de valor decorativo, sem um aluno desde 1912" (Primitivo Moucir, obr. cit., vol. $4 .^{\circ}$, p. 89 ).

(65) Primitivo MOACIR, obr. cit., vol. 4. ${ }^{\circ}$, p. 166 - "Puseram-se em almodela os títulos de bacharel em ciências e letras. Diretores ganharam com a condescendência ou a venalidede, sumas fabulosas" (idem, p. 88). 
de entidades religiosas vendo, com evidente exagêro, na :quiparação, que lhes concederia reconhecimento oficial, a eventualidade de transgressão da laicidade do ensino, por meio de atividade confessional; em relação aos colégios leigos, vendo a possibilidade de exploração da prerrogativa concedida pelo Estado.

Os alunos dos estabelecimentos particulares, portanto, para terem os certificados de exames de preparatórios necessários à inscrição no exame vestibular, deveriam apresentar-se em ginásio oficial, sendo examinados juntamente com os alunos dêstes últimos, ainda que não estivessem "obrigados as séries de matérias": "Daqui ım diante não haverá, como outrora, privilégio algum. Ensine quem quiser, levando os discípulos a exame no ginásio do govêrno". (66)

Os abusos e as deturpações do sistema de preparação para exames parcelados, por parte de colégios particulares, estariam duplamente prevenidos: pela restrição dos exames aos colégios oficiais, e pela limitação, a quatro, do número de disciplinas para cujos exames os alunos se poderiam inscrever, para os quais, além disso, sòmente uma época, a primeira dos alunos matriculados, haveria.

A inspeção, a que estariam sujeitos os colégios equiparados bem como os exames de preparatórios nêles realizados, exercida por inspetores do Conselho Superior de Ensino, não seria, de acôrdo ccm a reforma Maximiliano, instrumento de uma rígida uniformização do ensino secundário de todo o país.

Tinha-se, ao contrário, o propósito de preservar para os estabelecimentos estaduais equiparados, como para o Pedro II, a autonomia e a liberdade de movimentos necessários a uma real atividade educativa.

Nesse ponto, aliás, o pensamento de Maximiliano era antigo e bem definido. Realmente, já em 1911, na ccasiáo dos debates parlamentares em tôrno da lei Rivadávia, e então deputado Maximiliano afirmava em têrmos que ainda soam com plena atualidade: "Todos os sistemas de educação ou instrução que tendam para a uniformidade estão condenados. Na diversidade é que está o progresso. Na extensão da lista dos programas estabelecidos para as diferentes regiões de um vasto país, como o nosso, é que está a vantagem". (67)

E em 1918, em defesa dessas suas idéias de diversificação da educação nacional e de autonomia e flexibilidade das instituiçōes docentes, Maximiliano se dirige ao Conselho Superior de Ensino, nos seguintes têrmos: "Levo ao vosso conhecimento por me parecer digna de exame uma declaração que a êste Ministério tem sido feita por diretores de institutos equiparados aos oficiais. Exigem os inspetores que a série das matérias seja absolutamente igual à dos estabelecimentos oficiais. Não me parece qů esta exégese se coadune com a letra nem com espírito liberal da lei em vigor. (...) Exige-se,

(66) Premirrvo MOAcIR, obr. cit., vol. $4 .^{\circ}$, p. 90.

(67) PrIMIrIvo MOACIR, obr. cit., vol. $4 .^{\circ}$, p. 59. 
apenas, seriedade, ensino eficiente e aprovações merecidas; e não uma uniformidade incompativel com a liberdade e o progresso". (68)

Contudo, os velhos fatores negativos operantes na educação brasileira cedo começam a atuar contra o elevado sentido que Maximiliano quis introduzir no ensino secundário. Logo após a reforma, o decreto n. ${ }^{\circ} 11.895$, de 14 de janeiro de 1916, em obediência à lei do mesmo ano, permite aos estabelecimentos de ensino secundário localizados em cidades onde não houvesse colégios equiparados, submeterem seus alunos a exames de preparatórios perante bancas organizadas nos próprios estabelecimentos.

Como os Estados, em regra, mantinham apenas um estabelecimento oficial, nas respectivas capitais, estava assim aberta uma larga porta para que voltassem a proliferar colégios particulares dedicados especialmente à indústria de preparar alunos a exames de preparatórios. (68-A)

Acresce a êsse fato, de ordem geral, outro isolado, mas bem sintomático da resistência sempre presente aos esforços de melhoramento do ensino secundário, e desastroso por sua repercussão moral. Queremos nos referir ao chamado "decreto da gripe", como foi chamado o decreto n. 3.603 , de 11 de dezembro de 1918 , verdadeiro cataclismo educacional que malogrou grande

\section{(68) PrIMITIVo MOACIR, obr. cit., vol. $4 .^{\circ}$, pp. $176 / 7$.}

(68-A) Também foi concedida equiparacão, na vigência da lei MAXIMILIANo, depoıs de certa resistência do Conselho Superior de Ensino, a alguns colégios municipais. Foram pouços, contudo. Sôbre os exames de preparatórios nos colégios particulares, permitidos pelo decreto acima referido, encontramos nas atas das reuniōes do Conselho Superior de Ensino, reproduzidas no livro de Paranhos da Silva, algumas informações interessantes. $\mathrm{Na} \mathrm{8}{ }^{\mathrm{a}}$ sessão da reunião de fevereiro de 1916, o Conselheiro Porchat refere-se ao assunto dizendo quo "já se explora até com as disposições de lei ainda não executadas, como se verifica em relação à disposição legislativa que autoriza, em casos restritos, a concessão du bancas examinadoras especiais em colégios particulares provadamente idôneos." Para comprovar suas afirmações, lê anúncio de um colégio, do interior de São Paulo, que, avisando da abertura de sua matrícula, cita a disposição da lei orçamentária que previu os aludidos exames para dizer: "êste e outros ginásios, localizados em cidades onde não haja ginásios do Estado, passaram a terem (sic) novamente direito ao gozo das regalias de equiparação, sendo seus exames válidos para matrícula nos cursos superiores" (Paranhus da Silva, obr. cit., pp. 296/7). Na 4. ${ }^{a}$ sessão da mesma reunião, foi lido o parecer da Comissão de Institutos de Ensino Secundário, relativo ao pedido de bancas examinadoras feito pelo Colégio Leopoldinense, pelo qual se fica sabendo que o diretor dêsse colégio declarara no seu requerimento que "é fato virgem nas organizações escolares, quer nacionais quer estrangeiras, essa exigência de uma inscrição prévia de cinco meses", pedindo por isso fôsse considerada provisória a discriminação dos exames pedidos pelos alunos. "A Conissão, lemos no parecer, pensa não ser conveniente abrir mão dessa exigência, pois parece que o espírito do regulamento que baixou o decreto n. ${ }^{\circ} 11.895$ não permite que aluno de um instituto se inscreva para exames no outro e, sendo aluno do instituto o que se matricula na época competente, comêço do ano letivo, não se afigura à Comissão cousa tão extraordinária a exigência de inscrição antecipada, tanto mais quanto o contrário poderia abrir a porta a possíveis abusos" (obr. cit., pp. 322/3). Na mesma sessão o Conselheirc Ortiz Monteiro relata o parecer e analisa o decreto referido, que "reputa excessivamente liberal e falho nas suas exigências. Cita, para exemplo, a dificuldade de ajuizar da idoneidade do corpo docente. (...) Salienta a necessidade de verificação da matrícula e da frequiência regular dos alunos, a fim de evitar a intromissão de candidatos estranhos ao instituto. Entende que a concessão de bancas examinadoras dispensará equiparações, gerando abusos mais graves do que os verificados no regime daquelas" (obr. cit. p. 326). 
parte dos efeitos benéficos que a reforma Maximiliano produziria, se rigorosamente executada.

Como esclarece Adalberto Correia Sena, êsse decreto "foi promulgado logo após a epidemia de gripe, que assolou o país em 1918. O pretexto inicial era o de amparar os estudantes, duplamente prejudicados pela interrupção das aulas e pelas conseqüências da enfermidade. A verdade, porém, é que o projeto foi muito além de uma medida de emergência e acabou por se transformar na mais absurda e imoral distribuição de favores que já se praticara entre nós". (69)

De fato, êsse decreto representou a mais desbragada concessão de certificados de exames de preparatórios, para matrícula nos cursos superiores, que já se processara na história do ensino secundário. Se se desse a todos os colégios, particulares e estaduais, que gozavam de equiparaçãc; antes da Lei Rivadávia, a faculdade de realizarem exame sde preparatórios "à moda da casa", a produção de habilitados aos cursos superiores, em vários anos, seria menor do que a que se obteve, de um só jacto, pelo "decreto da gripe".

Mas não havia sòmente, nesse decreto, as facilidades para obtenção de certificados de preparatórios sem exames. Um dos dispositivos do mesmo dispensava também do exame vestibular o aluno que terminasse "o curso de preparatórios até 31 de março de 1919", e isso elidia até mesmo aquêle papel que o vestibular deveria ter, segundo Maximiliano, de "contrastear ó preparo fundamental" dado no curso secundário.

Em vista de um sintoma como o constituído pelo "decreto da gripe", assim como da forma por que se realizavam os exames de proparatórios, tanto nos colégios equiparados como nos não equiparados situados onde não havia dos primeiros, compreende-se que se restabelecessı o estado de insatisfação ante a situação do ensino secundário: "Embora a reforma de 1915, diz o Ministro Alfredo Pinto, em 1920 , tenha melhorado a desoladora situação criada por um regime de exagerada franquia, é manifesta a necessidade de uma remodelação para maior aperfeiçoamento dos nossos institutos de ensino". (70)

E é de nova ofensiva contra os exames parcelados de preparatórios, e contra a concepção do ensino secundário de que êstes aram a expressão, que se faz paladino êsse Ministro: ' $E$ ' óbvia a urgente necessidade de reorganização do Colégio Pedro II, arrancando-o à deplorável situação atual de simples curso de preparatórios. Em vez do processo de exames de preparatórios atualmente seguido, cumpre adotar um sistema de exames por grupoz de disciplinas, mais, racional, observada assim a rigorosa seriação, indispensável ao

(69) Adalberto Corrêa Sena - Legislação brasileira do ensino secundário Rio: Livraria Central, 1939, p. 210 - Afranio Peixoto, ao justificar, no $40^{\circ}$ Congresso Brasileiro de Instrução Superior e Secundária, realizado em 1922, o seu voto pela extinção das "provas de exames", dirá que o "decreto da gripe" consolidara a "opinião errada e mcnstruosa de que se estuda para fazer exame, e nảo se estuda para sab̀er o que se prova por exame, tanto assim que, por generosidade, se dispensou o exame sem exigir o estudo" (Primitivo Moacir, obr. cit., vol. $5^{\circ}$, p. 16).

(70) Primitrvo MOACIR, obr. cit., vol. $4 .{ }^{\circ}$, pp. 178/9. 
preparo intelectual da mocidade que se destina aos cursos superiores, corrigindo-se ao mesmo tempo a insuficiência e superficialidade dos estudos secundários em nosso país". (71)

Em 1921, volta o mesmo Ministro a insistir em que "problema que exige imediata solução é a reorganização do ensino secundário", apontando em especial, além da necessidade de instituição do "exame por grupos de disciplinas" para a conveniência de ser alterado o "dispositivo da reforma de 1915 que permite tais exames de preparatórios nos próprios institutos onde os examinandos estudaram, no sentido de tornar mais rigorosa a fiscalização e limitada as concessões". (72)

Também preocupação dêsse Ministro foi "aperfeiçoar e robustecer a inspeção, base essencial do êxito da ação fiscalizadora do Govêrno", (73) preocupação que se amplia no desiderato de reorganizar a administração federal de ensino, pela criação do Departamento Nacional de Instrução, "subordinado ao Ministro e não ao Ministério do Interior", e pela remodelação do Conselho Superior de Ensino, no sentido de ser dada a êste "atribuições amplas no dešnvolvimento e aperfeiçoamento da instrução pública". (74)

Também com o problema do professorado preocupa-se Alfredo Pinto, parecendo-lhe de "maior acêrto a instituição de uma Escola Normal Superior, federal, para a formação do professorado secundário". (75)

Em 1923, o Ministro João Luiz Alves, declarando que "a decadência incontestável do ensino secundário e superior e a deficiência do ensino primário estão a desafiar a atenção patriótica e a ação enérgica dos poderes públicos", (76) anuncia próxima reforma do ensino.

Em relação ao ensino secundário, seu intuito é "a seriação conveniente do ensino, suprimidos os exames parcelados de preparatórios". (77)

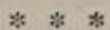

A última reforma do ensino, antes de 1930 , resultou da fusão de vários projetos e de sugestões de professôres, corporações docentes \& associações científicas e de educação, recebendo sua forma definitiva da parte de Rocha Vaz, e sendo tornada lei pelo Decreto n. ${ }^{\circ} 16.782-\mathrm{A}$, de 13 de janeiro de 1925 , assinado pelo Presidente Artur Bernardes e por João Luiz Alves como Ministro da Justiça e Negócios Interiores.

Em reformas precedentes, já houvera a preocupação de seus promulgadores de não ser feita obra quase puramente individual, expressiva apenas

(71) PRIMTTIVO MOACIR, obr. cit., vol. $44^{\circ}$, p. 179.

(72) PrIMITIVO MOACIR, obr. cit. vol. $4 .^{\circ}$, p. 183.

(73) Primitrvo MoAcir, obr. cit., vol. $4 .^{\circ}$, p. 179.

(74) Primitrvo MOAcIR, obr. cit., vol. 4., p. 190.

(75) Primrtryo MOAcIR, obr. cit., vol. $4 .^{\circ}$, p. 190.

(76) PRIMITIVo MOACIR, obr. cit., vol. $49^{\circ}$, p. 191.

(77) PrIMITIVo MOACIR, obr. cit., vol. $4 .^{\circ}$, p. 192. 
de pontos de vista doutrinários de ortodoxia sectária, como acontecera com as reformas Benjamin Constant e Rivadávia. Em nenhuma dessas, no entanto, o debate prévio foi tão amplo quanto em tôrno da reforma Rocha Vaz.

$\mathrm{O}$ debate e a própria reforma, aliás, não se restringiram à estrutura e áos demais aspectos do ensino secundário e do superior. Decorrendo a reforma da autorização de dispositivos das lois orçamentárias relativas a 1922 e a 1923 - os da primeira relativos à participação da União na difusão do ensino primário, assunto que vinha sendo objeto de atenção desde 1918, e os da segunda, além de alusivos ao ensino secundário e ao superior, relacionados com a organização da administração federal de ensino - teria de ser ela uma ampla estruturação do sistema nacional de educação, em quase todos os seus aspectos, como realmente o foi.

Um primeiro projeto de reforma foi preparado por Ramiz Galvão, então presidente do Conselho Superior de Ensino, e por uma comissão de que faziam parte nomez como Paulo de Frontin, Afonso Celso, Aloísio de Castro e Neto Campelo.

Quanto ao ensino secundário, o projeto incorpora idéias aprovadas pelo Congresșo Brasileiro de Instrução Secundária e Superior, (78) reunido em 1922, na capital do país, especialmente "a substituição dos exames parcelados do curso secundário pelos exames seriados, que garantem proparo metódico e melhor".

Do ponto de vista administrativo, trata o projeto da "organização do Departamento Nacional de Instrução Pública, sem demasias burocráticas", ao lado do Conselho Nacional de Instrução Pública, órgão opinativo e deliberativo.

Finalmente o projeto preconizava a criacão de uma Faculdade de Letras, dependendo de dotação orçamentária. (79)

A um "Projeto parcial de reforma do ensino, apresentado por alguns professônis", (80) segue-se o debate público, ao qual ocorrem Afranio Peixoto, A Liga Pedaǵógica, a Sociedade de Medicina e Cirurgia, a Acadenia Brasileira de Ciências, Alceu Amoroso Lima, Carneiro Leão e outros

Afrânio Peixoto afirma que no Brasil se estaria processando a "seleção dos incapazes, feita pelo ensino secundário", pedindo, contra isso "a proteção social dos mais aptos, por miaio das instituições de beneficência e solidariedade nacional (bôlsas, estipêndios, prêmios pecuniários, mesadas públicas, pupilos do Estado, etc.)". (81)

A concepção do ensino secunđário de Afrânio Peixoto, resume-se, nessa época, nas seguintes palavras: "O ensino secundário destinado a dar formação cultural geral indispensável a todos os que vão viver a vida social ou se

(78) V. Anais do $4 .^{\circ}$ Congresso Brasileiro de Instrução Superior e Secundária setembro a outubro de 1922 - Rio: Tip. Rua do Carmo, n. ${ }^{\circ} 55,1926$.

(79) Primitiva MOACIR, obr. cit., vol. $5 .^{\circ}$, pp. 9/11.

(80) PrIMITIVo MOACIR, obr. cit., vol. 5., p. 11.

(81) PrIMITIVo MOACIR, obr. cit., vol. $5 .^{\circ}$, pp. $12 / 3$. 
endereçam à especialização profissional, terá um conteúdo moderno, feito de línguas vivas, de ciências naturais, de ciências da sociedade, sadias e educativas, de literatura antiga e moderna, belas artes e exercícios salutares que preparam a humanidade para as mais difíceis aquisições de cultura integral. O estímulo para obtenção dos conhecimentos năo será uma tortura inquisitorial, contraproducente, como até agora, mas a própria beleza, curiosidade. interêsse e proveito dêsass conhecimentos... Os belos estudos, a ciência desinteressada, a arte pela arte, verdade pela verdade. Será para quando?"(82)

As sugestôes da Liǵa Pedagógíica não pairam em altitudes tão elevadas quanto as idéias de Afrânio Peixoto, referindo-se a quatro pontos principais:

“a) seriação obrigatória para o ensino secundário;

b) redução dos programas;

c) cursos de trabalhos manuais;

d) registro de professôres". (83)

A Sociedade de Medicina e Cirurgia, por sua vez, no que se refere ao ensino secundário, não revela em suas sugestões uma idéia muito clara dêsse ensino: "A instrução secundária será prática". (?) "Para ser admitido às escolas superiores, às comissões do Govêrno e ao funcionalismo público, o candidato deverá apresentar certificados dos seguintes preparatórios" - a enumeração inclui as matérias comuns ao currículo secundário, mais a eugenia e noções de direito usual e scciologia.

"Este o ensino prático, durante cinco anos, prazo mínimo para os exames. Além dêle, haverá o ensino ornamental, adquirido facultativamente nas escolas normais superiores, estabelecidas uma em cada capital do Estado, desenvolvendo o ensino das matemáticas, das línguas estrangeiras modernas, do latim, do grego, das literaturas, da geografia, da história da filosofia e das artes".

Os exames de preparatórios só poderão ser feitos nas capitais dos Estados, "perante as escolas normais superiores, por um programa essencialmente prático e uniforme para todo o país". As escolas normais são destinadas ao preparo do professorado secundário. (84)

As idéias do $\mathrm{Sr}$. Alceu Amoroso Lima referem-se especialmente ao objetivo. que a reforma do ensino secundário deveria ter, de nos tornar, os brasileiros, mais americanos: "Saímos dos colégics aqui sem ter a mínima noção do que somos realmente como povo, como nação". "Nenhuma, posso afirmá-lo com tôda segurança, nenhuma alteração mais necessária em nossos estudos secundários pode haver do que a criação dessa disciplina nova, dessa cadeira de Civilização Americana". (85)

Houvera, disse a Sociedade de Medicina e Cirurgia, um "ato de lealdade democrática", da parte do Ministro, ao se dispor êste a ouvir as sugestães de

(82) Primirivo MOACIR, obr. cit., vol. 5. ${ }^{\circ}$, p. 20.

(83) PrIMITrFo MOACr, obr. cit., vol. 5. ${ }^{\circ}$ pp. $20 / 1$.

(84) Primitivo MoAcIr, obr. cit., vol, 5. ${ }^{\circ}$, p. 22.

(85) Primitivo MOACIR, obr. cit., vol. 5. , pp. 24 e 26. 
quem as pudesse dar, e, a êsse ato, acudiram muitos, oferecendo "solução para o alargamento de nossa cultura e idéias para a difusão do ensino em seus vários aspectos", nas palavras de Primitivo. (86)

O número de sugestões fôra tão grande que o Ministro, na exposição de motivos da reforma, dirá: "Devo confessar que, diante do formidável arquivo de relatórios, pareceres, alvitres e sugestões que recebi e diante do desencontro, em pontos essenciais, de opiniōes doutas, me senti tomado de uma espécie de temor sagrado para ousar tocar nas pedras do edifício e procurar repará-lo, embora, de princípio, disposto a não lhe mudar a tradicional arquitetura. (...) Várias eram as questōes a resolver e muitas ficaram para soluções futuras e mais oportunas". (87)

Sôbre o ensino secundário, ressalta a exposição que a reforma era "sem grandes inovações", acrescentando: "A preconizada divisão em dois ciclos e a conseqüente bifurcação para melhor preparo das matérias mais recomendáveis a tal ou qual profissão, adotadas em alguns países, originam-se do pressuposto de que é preciso atender, desde cedo, sem perda de tempo, às variadas aptidões dos adolescentes. E' um ponto que sofrie crítica dos competentes. Diante dos males verificados, para operar desde logo, não podia ter a preocupação de tentar novidade sôbre as quais se tenha de manifestar ainda a experiência". (88)

O problema do ensino secundário é formulado, na exposição, nos seguintes têrmos: "O ensino secundário, com a sua dupla organização de ensino ginasial e de ensino de preparatórios, não poderia permanecer. Neste ensino o que se observa é o desejo de um preparo rápido e cada vez mais superficial nas matérias que habilitam para a matrícula nos cursos superiores. Esse não deve ser o objetivo do ensino secundário. Base indispensável para a matrícula nos cursos superiores, o ensino secundário deve ser encarado como um preparo fundamental e geral para a vida, qualquer que seja a profissão a que se diedicar o indivíduo. Sem grandes inovações na sua organização, o ensino secundário, segundo o projeto, será obrigatòriamente seriado, concluindo pelo estudo da filosofia. O curso será de seis anos". (89)

A adoção do regime de estudos secundários seriados, "mal esboçada na reforma de 1915" (90) e que deveria substituir definitivamente o sistema de preparação imediatista para exames de preparatórios, é, portanto, o objetivo de reforma, no respeitante ao ensino secundário.

"O ensino secundário, como prolongamento do ensino primário, para fornecer a cultura média geral do país, comprennderá um conjunto de estudos com a duração de seis anos", diz a lei.

"Constituem séries, acrescenta-se, as provas de conclusão de estudo das matérias, nos diversos anos do curso". "Não será permitido, lê-se adiante,

(85) Primitrvo MOACIR, obr, cit., vol, $5 .^{\circ}$, p. 31.

(87) PrIMITIVO MOACIR, obr. cit., vol. $5 .^{\circ}$ p. 40.

(88) PrImItrvo MOACIR, obr. cit,, vol, 5., p. 42.

(89) Primrrivo MOACIR, obr. cit., vol. 5. , p. 41.

(90) Primitivo MoAcIR, obr. cit., vol. 5. ${ }^{\circ}$ p. 35. 
acesso a um ano qualquer sem a aprovação nas matérias do ano anterior, quer nas que forem de simples promoção, quer nas que constituírem provas de conclusão das diversas séries". E ainda: "Não será facultado, em caso algum, prestar provas finais de mais de uma série em cada ano".

O curso secundário de seis anos representaria o curso completo, em sua feição de ensino formativo e cultural. Aos que completassem o sexto ano dar-se-ia, em conseqüência o grau de bacharel em ciências e letras. A completação do quinto ano, no entanto, era considerada suficiente à função preparatória do ensino secundário: "O certificado de aprovação final no $5 .^{\circ}$ ano áo curso secundário é condição indispensável para admissão a exame vestibular em qualquer curso superior, supridos os exames parcelados de preparatórios".

Tal como na lei Maximiliano, a ıquiparação fica restrita aos estabelecimentos de ensino secundário mantidos pelos Governos estaduais, condicionada, além disso, à fiscalização de inspetores, à obediência do regime de estudos prescrito pela reforma e até mesmo à adoção de regimento interno idêntico ao do Pedro II.

Entretanto, "abolidos os exames de preparatórios, enquanto não disseminados os institutos ginasiais idênticos ao Pedro II, era indispensável prover a sua deficiência, tendo :m atenção o número de estudantes do curso secundário em todo o país e as dificuldades de comunicação. O projeto o fêz, instituindo juntas examinadoras, de composição idônea, cuja concessão a estabelecimentos particuleres obedece a preceitos que garantem a seriedade do ensino". (91)

O que, na época da vigência da loi Maximiliano, fôra um ecréscimo a essa reforma, acréscimo de cunho limitado, pois só nas localidades onde não houvesse estabelecimento oficial poderiam funcionar bancas examinadores, torna-se na lei Rocha Vaz, como se vê, a solução geral e prèviamente aceita para o problema do ensino privado, podendo qualquer estabelecimento particular obter junta examinadora, desde que provassse dispor de corpo docente idôneo o obedecer nos seus cursos a programa igual ao do Pedro II.

Além disso, na reforma Maximiliano a concessão de bancas examinadoras apenas prolongava aquela atitude de tolerância dos exames de preparatórios, enquanto na lei Rocha Vaz torna-se ela instrumento da implantação do sistema de seriação dos estudos nos colégios particulares: os exames de cada aluno seriam restritos às matérias de cada ano do curso, observada rigorosamente a seriação estabelecida para o Pedro II.

Prolongando e ampliando, assim, as realizações da fase da lei Maximiliano. a reforma Rocha Vaz preparou ao mesmo tempo a definitiva implantação do ensino secundário como um curso regular, passível de preencher funções mais amplas que a de preparação fragmentária aos cursos superiores, que se tornará definitiva realidade com as reformas posteriories a 1930: a de Francisco Campos e a de Gustavo Capanema.

(91) PrIMITIVo MOACIR, obr. cit., vol. 5., p. 42. 
Não queremos dizer que ela tenha efetivado, plenamente, as funções que um verdadeiro ensino secundário deve preencher, numa sociedade moderna. Também não diríamos isso nem mesmo das reformas Campos e Capanema. Pois ocorreu que, na ocasião dela, já começavam a atuar aquêles fatories de transformação social que se tornam avassaladores depois de 1930, traduzidos, a partir daí, na tremenda expansão do ensino secundário, e operantes do sentido de tornar superada a concepção de um ensino secundário formativo e seletivo.

Mas, além da atuação dêsses, tinha essa reforma de lutar, como tôdas as anteriores, e também as posteriores, contra a ação daqueles outros fatôres, decorrentes das condições morais e culturais de nossa formação, que tornam tôda obra de melhoramento educacional uma tarefa heróica, incompreendida, hostilizada.

A luta continuará, depois de 1930, facilitada, pelo menos, no que diz respeito à legitimidade da ação federal sôbre o ensino secundário de todo o país, pois, naquele ano, a revolução vitoriosa derroga a Constituição de 1891, e, em 1934, a nova Constituição estabelece expressamente, como competência da União, traçar as diretrizes da educação nacional e fixar o plano nacional de educação, assim como fiscalizar os estabelecimentos de ensino secundário e superior. 